\title{
The EU and Climate Change Policy: Law, Politics and Prominence at Different Levels
}

\section{Chad Damro, lain Hardie \& Donald MacKenzie}

\begin{abstract}
The European Union (EU) is a prominent player in the politics of climate change, operating as an authoritative regional actor that influences policy-making at the national and international levels. The EU's climate change policies are thus subjected to multiple pressures that arise from the domestic politics of its twenty-seven individual member states and the international politics of non-EU states with which it negotiates. Facing these multiple pressures, how and why could such a non-traditional actor develop into a prominent player at different levels of climate change policy-making? This article argues that the EU's rise to prominence can be understood by tracking a number of historical-legal institutional developments at the domestic and international levels. The article also provides a preliminary investigation of the EU emissions trading scheme, a new institutional mechanism that illustrates the policy pressures arising from different levels.
\end{abstract}

WHILE THE EUROPEAN UNION (EU) IS A PROMINENT PLAYER IN THE POLITICS OF climate change, it is neither a state nor an international organisation in the traditional sense. ${ }^{1}$ Rather, it operates as a proactive and authoritative regional actor that can influence policy-making in significant ways at the national and international levels. The EU's legal and political capacity to promulgate domestic climate change legislation and to play a significant role in international environmental politics arises from the fact that its twenty-seven member states have pooled sovereignty in environmental policymaking. Its unique nature and position also means that EU policy-making is subject to multiple pressures from both the national and international levels, a situation that potentially complicates social scientific efforts to explain the causes of initiatives and outcomes in EU climate change policy.

Despite its complex, internal institutional design, the EU's impact is directly apparent at the national and regional levels. The EU has and continues to play a significant role in designing European climate change legislation as well as encouraging and interacting with national climate change activity within its Member States. Its European Climate Change Programme (ECCP) in 2000, began a process of screening measures in the fields of energy, transport and industry. According to the European Commission, since the launch of the ECCP, the EU has put in place more than thirty initiatives to counter climate change (2006: 1). Table 1 lists the key initiatives that have resulted from this programme.

\footnotetext{
${ }^{1}$ For simplicity, this study refers to the "EU" when discussing the Union's climate change policies. The term "EC" will be used in this article only when necessary for legal clarity and when citing secondary sources.
} 
Table 1: The European Climate Change Programme-Key Measures as of $2006^{2}$

\begin{tabular}{|c|c|c|c|}
\hline Measure & $\begin{array}{l}\text { Reduction } \\
\text { potential (Mt } \mathrm{CO}_{2-} \\
\text { eq.) } \\
\text { EU-15, } 2010\end{array}$ & Entry into Force & $\begin{array}{l}\text { Starting to } \\
\text { Deliver }\end{array}$ \\
\hline $\begin{array}{l}\text { EU emission trading } \\
\text { scheme }\end{array}$ & - & 2003 & 2005 \\
\hline $\begin{array}{l}\text { Link JI/CDM to } \\
\text { emission trading }\end{array}$ & - & 2004 & $2005 / 2008$ \\
\hline $\begin{array}{l}\text { Directive on } \\
\text { promotion of } \\
\text { electricity from } \\
\text { renewable energy } \\
\text { sources }\end{array}$ & $100-125$ & 2001 & 2003 \\
\hline $\begin{array}{l}\text { Directive on } \\
\text { promotion of } \mathrm{CHP}\end{array}$ & 65 & 2004 & 2006 \\
\hline $\begin{array}{l}\text { Directive on energy } \\
\text { performance of } \\
\text { buildings }\end{array}$ & $35-45$ & 2003 & 2006 \\
\hline $\begin{array}{l}\text { Directive on } \\
\text { promotion of } \\
\text { transport biofuels }\end{array}$ & $35-40$ & 2003 & 2005 \\
\hline Landfill directive & 40 & 1999 & 2000 \\
\hline $\begin{array}{l}\text { ACEA/JAMA/KAMA } \\
\text { voluntary } \\
\text { commitment }\end{array}$ & $75-80$ & 1998 & 1999 \\
\hline $\begin{array}{l}\text { Energy labelling } \\
\text { directives }\end{array}$ & 20 & 1992 & 1993 \\
\hline Biomass action plan & - & 2005 & 2006 \\
\hline
\end{tabular}

Source: Jos Delbeke (2006: 6).

At the international level, the EU has been a prominent player in climate change politics via the process initiated by the 1992 United Nations Framework Convention on Climate Change (UNFCCC). ${ }^{3}$ The UNFCCC provided a non-binding framework for further international negotiations on climate change and provided a venue in which the EU could actively participate despite its non-traditional nature. The subsequent negotiations occurred as the regular, so-called Conferences of the Parties (COPs). Following the 1997 COP-3 that resulted in the signing of the Kyoto Protocol, the EU played a prominent role as an advocate for the ratification of the agreement. ${ }^{4}$ The EU was rewarded for its efforts in 2005 when enough countries ratified the Protocol for it to enter into force. Although its position has shifted and activity has fluctuated during these lengthy negotiations, the Union is now often described as a 'leader' or

2 Delbeke also notes important, climate change related developments in voluntary commitments from auto manufacturers to improve $\mathrm{CO}_{2}$ efficiency, an energy labelling system for consumers, methane reduction initiatives for landfills, fluorinated gas substitution regulation, work on energy services and energy using products, and consumer incentives for $\mathrm{CO}_{2}$ friendly automobiles (2006: 5-7). For more on the EU's climate change policies, see http://europa.eu/scadplus/leg/en/s15012.htm. Oberthür and Tänzler (2007: 255) also list many EU climate change policies and individual, national policies by Member States.

${ }^{3}$ The UNFCCC was agreed at the 1992 UN Conference on Environment and Development in Rio de Janeiro and entered into force in March 1994.

${ }^{4}$ At COP-7, held in Marrakech, Morocco, from 29 October to 9 November 2001, the Parties adopted the Marrakech Accords, a comprehensive set of detailed rules for implementing the Protocol. The EU and its Member States ratified the Marrakech Agreement in 2002. 
'frontrunner' in international environmental politics. ${ }^{5}$ While the academic debates over 'leadership' are outside the analytical focus of this article, the EU does operate as a prominent actor in the ongoing negotiations over the types of arrangements that will follow the expiration of Kyoto in 2012. As a party to the Kyoto Protocol, the EU has participated prominently in important and intensive interactions with non-members and international organisations. According to Oberthür, "the commitments entered into under the climate change regime have affected the rules of other international institutions and EU legal instruments" (2006: 56-58), resulting in various types of institutional interaction across different levels. More generally, the EU remains an active and prominent protagonist for changes in global environmental governance, especially through the United Nations and its associated bodies (Vogler 2005).

Given its domestic and international activity, the EU provides an interesting case in which multiple causes interact across national, regional and international levels of analysis. This climate change activity at different levels begs the following question: How and why has a non-traditional, regional actor such as the EU become a prominent player in climate change politics at both the national and international levels? This question is particularly intriguing considering that, at its origins in 1957, the Union had no authority over domestic environmental policy generally, much less specific authority to engage in international climate change negotiations.

It is worth emphasising at the outset that this article does not intend to test the comparative influence of multiple pressures from different levels. Rather, the article asserts that the conditions for the EU's rise to prominence in this policy area can be understood by tracking a number of historical-legal institutional developments that have occurred at the domestic and international levels. While these changes have created opportunities for the EU to engage in multilateral climate change politics, the shifting authority from the Member States to the EU institutions has also increased internal policy-making complexity. The following study of the institutional developments should provide a basis for further analyses of EU climate change policy that incorporate more systematically the role of various actors at different levels. ${ }^{6}$

The article proceeds in the following manner. The next section describes the historical and legal establishment of the EU's authority to engage in environmental policymaking within the Union. The third section explores the ways in which the EU acquired its ability to engage in international environmental politics. The fourth section investigates the EU's emissions trading scheme, a climate change mechanism that illustrates the institutional complexity of the Union as well as the political interaction that occurs between domestic and international levels. The final section provides a summary of the findings and suggests different directions for further research that may help to illuminate the politics of EU climate change policies and policy-making.

\section{Internal Institutional Developments and EU Environmental Policy-Making}

Environmental policy, much less the specifics of climate change, did not appear in the original 1957 Treaty of Rome that established the European Economic Community. ${ }^{7}$ While this might seem a surprising oversight today, it is understandable in historical terms. In the 1950s, environmental policy was not a highly salient political issue for an organisation that was focusing on economic efforts to help recover from the

\footnotetext{
${ }^{5}$ For work on the EU as a 'leader' in international environmental politics, see Schreurs and Tiberghien (2007), Damro (2006), Skodvin and Andresen (2006), Wettestad (2005), Zito (2005), Vig and Faure (2004), Christiansen and Wettestad (2003), Hovi et al. (2003), Andresen and Agrawala (2002), Gupta and Ringius (2001), Gupta and Grubb (2000).

${ }^{6}$ See, for example, efforts investigating the subnational/national level in individual EU Member States (Harris 2007, Compston and Bailey 2008, Fisher 2004, Vig and Faure 2004) and their interaction at the EU level (Damro and MacKenzie 2008, Delreux 2006, Janning 2005, Barket et al. 2001).

${ }^{7}$ For a useful history and introduction to EU environmental policy, see Lenschow (2005).
} 
devastating effects of war. These early regional efforts targeted economic integration, not environmental protection. But how could the EU have developed such a formidable role in environmental policy today given these humble origins? A number of internal developments, which will be identified below in chronological order, helped to establish the EU's influence in environmental policy and contributed to its ability to engage in international climate change negotiations.

The first major development was a legal decision by the European Court of Justice. The 1971 ERTA Decision was not an environment-specific ruling; it addressed cross-border transportation policy issues within the Union. ${ }^{8}$ Nevertheless, the language in the ruling provided an opening for the Commission to argue for external competence in environmental policy and extended the EU's "external competence in one vast stroke" across multiple policy areas (Macrory and Hession 1996: 123). According to the decision, when the European Community has the right (that is, acquires legal competence) to legislate internally, it also has the right to act externally in matters that might affect that internal legislation. As a result, the EU typically "first legislates and then exercises external jurisdiction. The Court's case law did not, however, clarify whether the Commission or the Council Presidency would represent the Community in international fora...Furthermore, the Court's decision did not change the international status of the Community's member-states" (Sbragia 1998a: 287-88).

Not long after the ERTA decision, the EU issued its first Environmental Action Programme (EAP). These non-binding EAPs set out the framework and strategies and priorities for EU environmental policy-making. The first was issued in 1973. During the early 1970s, the Commission began including environmental cooperation with third parties in its EAPs. The Commission linked competence over environmental policy with its competence in trade policy by arguing that implementation of international environmental agreements could affect EU competitiveness. Consequently, during the 1970 s, the EU became party to a number of multilateral environmental agreements. The $5^{\text {th }}$ EAP (1993) included climate change as a 'theme'. The most recent $6^{\text {th }}$ EAP (a decision of the European Parliament and Council) runs from 2002-2012, and includes four priority areas: climate change, nature and biodiversity, environment and health, and natural resources and waste. The EU's environmental policy generally conforms to its EAPs, which helps to give it internal coherence and consistency.

In 1981, the Commission established the Directorate-General XI, which would become the DG Environment of today. It represents a serious effort at institutionalising environmental policy and reflects "an institutional acknowledgment of the growing importance of environmental protection within the Community's policy portfolio. It has also provided the main channel for environmental groups trying to pressure the Commission toward 'greener' proposals, with the result that it has often been treated with suspicion by those within the Commission concerned with economic development and market liberalization" (Sbragia 1998b: 170). DG Environment now provides a home for the coordination of EU environmental policy, including the Union's international relations.

The first inclusion of environmental policy in the primary legislation of the EU came with the 1986 Single European Act (SEA). The SEA incorporated environmental policy into the EU's treaty structure, giving it an explicit legal basis from which to make policy. Before the SEA, "the Commission primarily based [environmental] legislation under Treaty Article 100 (harmonizing national regulations that inhibit common market trade) or Article 235 (permitting the pursuit of Community objectives in the course of operating the common market where the Treaty has not provided the necessary powers). Accordingly, an important rationale for Community environmental activity was protecting the common market from national environmental legislation that acts as trade (non-tariff) barriers" (Zito 2005: 367). The SEA also gave the EU a legal basis for

\footnotetext{
${ }^{8}$ Case 22/70 Re the European Road Transport Agreement: EC Commission v. EC Council 1971 ELR 60-79.
} 
negotiating international environmental agreements in Article 130r (5), which states that "within their respective spheres of competence, the Community and the Member States shall cooperate with third countries and with the relevant international organizations" (Sbragia 1998a: 289).

In 1990, the EU took another internal institutional stride when the Council approved the creation of the European Environment Agency (EEA). The key role of the EEA is that of information provider and analyst. While it is not directly involved in international decision-making, it does interact with international partners, including European Economic Area member countries (Iceland, Norway, Leichtenstein), accession countries, international organisations (e.g., UNEP, WHO, OECD), and the Balkan countries. ${ }^{9}$ Much of the public information the EEA provides covers developments in the science and policy of climate change at both national and international levels.

In 1992, the EU experienced another significant internal development with implications for climate change and international negotiations. The Maastricht Treaty granted the EU competence to conclude international environmental agreements, which then are binding on the Union's institutions and its Member States. The Treaty also "included a new objective for Community action: Community policy on the environment should contribute to 'promoting measures at international level to deal with regional or worldwide environmental problems'" (Sbragia 1998a: 290).

These internal developments helped to establish environmental policy within the EU and increased the authority of the supranational European Commission. As Zito argues, "The EU's ability to act in its own right as an environmental actor is a by-product of the historical evolution of complex institutional forces. Just as the EU was expanding its environmental policy scope, it was also enhancing enormously its international profile" (2005: 367). It is to the EU's international profile that the article now turns.

\section{International Developments and EU Activity in Multilateral Climate Change Policy- Making}

As a result of the internal developments noted in the previous section, the EU has established itself as a prominent environmental actor at the national and regional level. However, it also had to establish an external legal competence for it to become a prominent international actor in this policy area. By doing so, it could move forward to engage more actively in international environmental politics.

The EU's legal competence in international environmental politics is known as shared (or mixed) competence. ${ }^{10}$ Legal competence is important as it determines which institutions have the authority to act internationally on behalf of the EU. The EU's system of shared competence determines who will represent the Union at international negotiations, sign and ratify agreements reached at the negotiations, and implement domestic measures necessary to meet commitments under such agreements. ${ }^{11}$ In theory, the Commission speaks for the EU when areas under the Union's exclusive competence are being discussed and the Member State holding the Presidency speaks

\footnotetext{
${ }^{9}$ It is noteworthy that while Turkey is not a member of the EU, it is a member of the EEA.

10 This differs greatly from areas traditionally guided by exclusive competence, like trade policy. For useful discussions of shared competence, see Delreux (2006), Vogler (1999) and Macrory and Hession (1996). While the 1957 Treaty of Rome gave express external competences to the European Economic Communities in only two policy areas (trade and association agreements with third states), today, under the Treaty of Nice, the EU's express external competence includes financial and monetary policy, external trade policy, research policy, environmental policy, development cooperation and association agreements (Delreux 2006: 234).

${ }^{11}$ For discussions of the practicalities of EU representation in negotiations and signing, see Delreux (2006) and Macrory and Hession (1996). For recent work on implementation and enforcement, see Hovi et al. (2007).
} 
for the EU when areas of shared competence are being considered. Despite this legal distinction, the Commission can be asked to represent the EU when areas of mixed competence are being discussed (Sbragia 1998a: 293: 295). The Commission may also be involved in negotiations more informally: "No matter who negotiates on behalf of the EU, intensive coordination between the different European actors during international environmental negotiations and conferences is part of the day-to-day practice. These on the spot coordination meetings take place at the location of the international negotiations, mostly every morning and every evening during the international negotiations" (Delreux 2006: 244).

While the system of shared competence has become standard operating procedure within the EU, it can create the potential for confusion at international negotiations (Sbragia 1998a: 294; Macrory and Hession 1996: 113). For example, multilateral environmental negotiations often take years, but the Union's Presidency lasts only six months, which can produce a puzzling series of interlocutors. ${ }^{12}$ Likewise, because environmental negotiations often touch upon other policy areas, the institution legally charged with representing the Union can change back and forth. ${ }^{13}$ Under such conditions, third parties may wonder with whom they are actually negotiating, especially if different EU representatives and institutions speak across time on the different policy areas being discussed. This potential for confusion can also weaken the EU's credibility in the minds of some third party negotiators when it comes to implementation and enforcement commitments.

But how did the EU get to this complex institutional arrangement for external representation? The answer is that "The path towards external recognition has often been a struggle" (Delreux 2006: 233); the internal developments mentioned above played a role, but international developments were also necessary to complete the Union's transformation. The success of the EU's transformation is reflected in the fact that it has signed over sixty multilateral environmental agreements. ${ }^{14}$ But to do so, it has had to acquire recognition from third-party negotiators and negotiating forums.

The United Nations (UN) is the primary forum in which international climate change negotiations occur. Representation in international negotiations often requires membership in the associated organisation or at least recognition by negotiating partners (Jupille and Caporaso 1998). The EU's first strides in acquiring third-party recognition occurred with the passing of a 1974 UN General Assembly Resolution that granted the EU only permanent observer status, including participation rights, in the General Assembly and the Economic and Social Council. ${ }^{15}$ While the resolution recognised the EU's rights to participate in these important UN institutions, it did not address a role for the Union in multilateral environmental negotiations that might take place outside of those institutions.

In 1979, the EU was granted the status of Regional Economic Integration Organisation (REIO), which allowed the Union to participate in multilateral environmental negotiations. ${ }^{16}$ As a REIO, the EU can be party to a convention even if none of its

\footnotetext{
12 See European Commission (2001: 27). In contrast, scholars have also argued that the EU's variable representation is no longer a significant obstacle for third party negotiators (Vogler 1999).

${ }^{13}$ Negotiations over environmental policy can touch upon industrial policy, consumer policy, overseas economic development policy, science and research policy, agricultural policy, marine/fisheries policy, technology policy, fiscal policy, energy policy, transport policy and humanitarian assistance policy.

${ }_{14}$ According to some measures, the EU is signatory to hundreds of multilateral environmental agreements, including multiple renewals of pre-existing ones.

15 UNGA Resolution 3208 (XXIX), 11 October 1974. According to this arrangement, the EC (represented by the European Commission) and not the EU, formally possesses permanent observer status.

${ }^{16}$ At the domestic level, Sbragia (1998a: 289) points out that "The link between the Community and other international bodies was explicitly recognized by the European Council held in Stuttgart in June 1983. The Council stated it saw the necessity to take coordinated and effective initiatives both within the Community and internationally, particularly within the ECE, in combating pollution (Johnson and Corcelle 1995: 22)".
} 
Member States are party to the convention. Where REIO status does not apply, participation rights have been negotiated on a case-by-case basis; EU participation, therefore, still has to be negotiated and approved on an ad hoc basis for different multilateral environmental negotiations. Specifically in climate change negotiations, Article 22 of the Climate Change Convention "provides for ratification of the Convention by states and 'Regional Economic Integration Organizations'"' (Macrory and Hession 1996: 112). ${ }^{17}$ This legal measure ultimately allowed the EU to sign onto and ratify the Kyoto Protocol in May 2002, making it the only regional organisation to do so.

Following from the UN's 1974 resolution and its REIO status, the EU also maintains active institutional relations (as an observer) within the UN system of governance via two of its key bodies for dealing with environmental issues: the UN Environment Programme and the Commission on Sustainable Development. Although it does not possess full participatory rights, the EU is a major financial donor and has become a prominent advocate of numerous proposals to re-organise global environmental governance (Damro 2006; Vogler 2005; European Commission 2004).

The EU's ability to engage in multilateral environmental negotiations is also apparent in its ability to attain objectives and to manage lengthy UN negotiations on climate change. For example, one need only investigate the UNFCCC's Kyoto Process (1992present). These long negotiations were pushed forward by the EU despite the withdrawal of the world's largest greenhouse gas emitter-the United States of America. The prominence of the EU's role certainly fluctuated during this process (Grubb and Yamin 2001). Nevertheless, the EU seems to have demonstrated the ability to act as a prominent player by encouraging enough countries to ratify the Protocol for it to come into force in February 2005. The EU also may have learned the skill of issue linkage when it seemed to convince Russia to ratify the Protocol in exchange for the Union's support of Russia's WTO membership bid (Damro 2006).

Much of the EU's success in the UNFCCC's Kyoto Process is due to the ability of its Member States to understand and operate within its complex institutional framework and system of shared competence. At the same time, the EU's decisions and behaviour are also clearly influenced by international factors and the need for recognition by third parties. These institutional arrangements and pressures from the national and international levels can create feedback that results in new institutional developments at the regional European level, as will be highlighted in the next section.

\section{The EU Emissions Trading Scheme}

Given the various institutional factors affecting the EU's role in climate change policy at different levels, it seems sensible to explore an empirical case in which the Union has played a prominent role. The establishment of the EU's internal Emissions Trading Scheme (ETS) demonstrates how the Union can operate as an authoritative regional point of interaction between the national and international levels. At the national level, the ETS has become a 'flagship' for EU climate change policy (Delbeke 2006: 7) and now covers roughly half of the EU's $\mathrm{CO}_{2}$ emissions. At the international level, it represents a case in which the EU changed its position and now seems to be engaging as a prominent player. Despite these positive outcomes, the EU's creation of the world's largest and most comprehensive (European Commission 2006: 1) emissions trading scheme faced high set-up costs. Add to this the international uncertainty surrounding

\footnotetext{
17 In accordance with the Decision of the Council OJ L33 07/2/94 p11 Conclusion of the Framework Convention on Climate Change, "The Community acceded to the UN Framework Convention on Climate Change with the Members States and has therefore arrived at a full participatory role in the future developments of the Convention, including the Conferences of Parties" (Macrory and Hession 1996: 112).
} 
the Kyoto Protocol at the time the EU began working on its ETS, and the Union's decision to move forward with the initiative seems particularly puzzling and risky.

The decision to create a new market for carbon trading reveals the complicated causality that can occur across different levels when the EU engages in climate change policy. Many factors from the national, regional (EU) and international levels certainly had an impact on the decision to move forward with emissions trading. A number of studies have problematised and tried to disentangle these multiple causes. While this is not the place to provide a comprehensive review of the relevant literature, it is worth noting briefly a few studies for their efforts to disentangle these multiple causes.

First, studies have explored the EU's motivations for adopting the idea of emissions trading after initially resisting it in the international negotiations. Damro and LuacesMendez (2003) argue that the EU adopted the idea of emissions trading as part of a process of policy learning that drew from US experiences with similar domestic schemes. ${ }^{18}$ Cass (2005) argues that the EU's advocacy for emissions trading is best understood as the result of shifting 'frames' of debate that allowed the Union to overcome norms that had previously prevented its support for such a market-based mechanism. Second, other studies have focused their analyses on the reasons why the EU issued its 2003 directive establishing the ETS. Wettestad (2005) tends to emphasise the central role played by the European Commission while Oberthür and Tänzler (2007) and Oberthür (2006) tend to emphasise the causal role of international regimes. The sum total of these scholarly efforts suggests that explanations of emissions trading and the ETS need to consider a significant causal role for domestic and international factors..$^{19}$ Likewise, future analyses of multiple factors will be necessary to explain the impact that the EU's ETS will (or will not) have on global efforts to create an international emissions trading system.

Keeping with the analytical theme of this article, it is worth trying to identify important institutional and other pressures from different levels that might help to explain the rise and operation of the ETS. At its most basic level, the EU's ETS arose from the UNFCCC process and the resulting Kyoto commitments. Early in the negotiations, the EU resisted the market-based instrument of emissions trading in favour of more command-andcontrol regulatory and taxation schemes. ${ }^{20}$ By contrast, the USA was the primary driver of the new instrument, based on its previous experience with similar domestic trading systems. ${ }^{21}$ These differing positions were a point of contention from the outset of the negotiations. As Sbragia points out, as early as "1992 EU Finance Ministers insisted that any EU carbon tax be implemented only on condition that the USA and Japan acted in kind. Japan agreed on condition that the USA enact some kind of carbon tax. The Clinton administration refused" (1998a: 299). Despite this early stalemate, the EU's gradual adoption of the idea of emissions trading allowed for compromise and created an opportunity for progress in the negotiations.

But what could have triggered the EU's change of position? Some of the change can certainly be attributed to an international process of policy learning. For example, one Brussels policy-maker noted direct policy learning on this issue through transatlantic visits by Commission officials to observe US trading schemes in action. ${ }^{22}$ This claim is supported by the Commission's statement that "The ETS's 'cap and trade' system was inspired by a United States model introduced in the 1990s to curb acid rain" (European

\footnotetext{
${ }^{18}$ For a study that emphasises 'ossification' as the opposite of policy learning within the context of climate change, see Depledge (2006).

${ }^{19}$ For an analysis of climate change politics that challenges the necessity of investigating domestic politics, see Grundig (2006).

${ }^{20}$ An early Commission predilection for carbon taxes is apparent in the fact that Carlo Ripa de Meana, the then-Environment Commissioner, refused to go to the 1992 Rio Summit because of the lack of commitment to carbon taxes by the Council of Ministers (Sbragia with Damro 1999: 61).

${ }^{21}$ Oberthür and Tänzler (2007: 264), Christiansen and Wettestad (2003), Damro and Mendez (2003).

${ }^{22}$ Expert Interview, Copenhagen, Denmark, 14 March 2007.
} 
Commission 2006: 2). Domestic politics and institutional obstacles also played a role. In the early 1990s, the Commission realised that it would face a difficult, if not impossible, battle with its Member States over a carbon and/or energy tax. Crucially, both fiscal instruments and energy policy require unanimity (as opposed to qualified majority) in the Council of Ministers. Since the Commission would be unlikely to convince all Member States in the Council to agree to an EU carbon/energy tax, the proposal faded (Braun 2008). ${ }^{23}$ The combination, therefore, of international policy learning and the domestic politics and institutional constraints of taxation highlight the pressures coming from different levels. Indeed, as one Brussels insider noted of the cross-level pressures, "So, we saw that the tax was failing on the one hand and we saw that emissions trading was pushed by the United States, so the two were coinciding and so we changed approach". ${ }^{24}$

As the EU was gradually changing its position, the US was gradually reducing its commitment to the Kyoto Process - for example, President Clinton decided not to send the Protocol to a Senate that publicly opposed ratification, and President Bush effectively withdrew from the process in March 2001. As a result, the EU became the most prominent advocate for emissions trading within the Kyoto framework (Schreurs and Tiberghien 2007: 20; Wettestad 2005: 17). Cass adds that "Once the United States became disassociated with the trading proposals, the European Union was able to enter the void with greater credibility with the European public and environmental NGOs and play a more innovative role in the development of the trading mechanism" (Wettestad 2005: 40).

As this international role and commitment evolved, the EU then began to push for the creation of its own domestic, Europe-wide ETS - a costly new policy initiative that would create an entire new market as a potential complement to any future international emissions trading scheme. Despite the costs, the EU moved forward very rapidly with the establishment of this new policy instrument. As Oberthür and Tänzler (2007: 266) note, "the discussions on setting up an EU-wide system of GHG emissions trading advanced at a high speed after the European Commission first declared in 1998 that 'the Community could set up its own internal trading scheme by $2005^{\prime \prime \prime} .25$

The speed with which the EU created its ETS is particularly noteworthy because the Union lacked previous experience with such a market-based mechanism (Wettestad 2005). The fundamentals, however, of emissions trading are rather straight-forward. The European Commission (2006: 1) itself provides a concise description of how the ETS is intended to operate:

...large emitters of greenhouse gases receive an annual allotment from their national governments specifying the amount of $\mathrm{CO}_{2}$ they may release into the atmosphere each year. Emitters may sell any 'surplus' allowances or credits to EU-based companies that need help to meet their targets. Emitters exceeding their allowances may also choose to invest in ways to reduce their emissions. By providing a financial incentive to curb $\mathrm{CO}_{2}$ emissions-essentially putting a price on carbon emissions-the ETS is helping to change the mindset of European business.

\footnotetext{
${ }^{23}$ According to one insider, the UK offered strong resistance to the tax and was supported to varying degrees at different times by Spain, Ireland, Germany and Greece (Expert Interview, Copenhagen, Denmark, 14 March 2007).

${ }^{24}$ Expert Interview, Copenhagen, Denmark, 13 March 2007.

25 Oberthür and Tänzler (2007: 266) also identify the following rapid timeline for important institutional developments related to the ETS: "In October 2001, the Commission presented a proposal for an EC Directive on an EU-wide emissions trading scheme (European Commission 2001a: 581). EU environment ministers agreed on the rules for the EU-wide trading scheme in December 2002 (European Council 2002) and the resulting EU directive entered into force in October 2003 (European Council 2003a). The EU started a pilot phase of the scheme in 2005, which is to be followed by a full-blown system that will become operational in 2008 (from the beginning of the 2008-12 Kyoto Protocol commitment period)".
} 
As the Commission began organising its regional ETS, it also had to contend with budding national emissions trading schemes in Member States such as the UK and Denmark. Without proper coordination, these national schemes could develop into instruments that were incompatible with the EU-level ETS. Such national schemes could also create advantages for certain Member States. As Zito (2005: 371) argues, "The Netherlands and the UK have been seeking to develop their ideas on this system in order to gain some first mover advantage and 'upload' their ideas within the larger EU debate and prevent disruption to their domestic systems (Jordan et al. 2005)". The UK national scheme provides a useful example regarding the potential for incompatibility. In particular, the British began developing a voluntary scheme, while the EU supported a mandatory scheme. This incompatibility helped to encourage the rapid development of the EU's ETS. As one Brussels insider notes

\begin{abstract}
We wanted to signal very early on that we were developing our own scheme and that our scheme was different in its approach. And to be frank, in 2001, when we made the proposal, the UK was already keen on emissions trading. They had, however, their own vision of how trading would work. It was a voluntary approach, driven by financial incentives, in which electricity generators would not be covered directly, but users of electricity would be made responsible for the emissions arising from electricity generation. The UK had difficulty in persuading other Member States of the merits of their scheme, particularly in terms of its complexity. It took a good twelve months of negotiation for the UK to reconsider its position. The Commission was anxious to ensure a complete dovetailing and compatibility with the Kyoto Protocol, which basically made the country where emissions occurred accountable, irrespective of where electricity might be consumed. And the UK's 'indirect' emissions approach was different. ${ }^{26}$
\end{abstract}

While the creation and operation of the ETS is often cited by the Commission as a success (European Commission 2006), its record has been somewhat mixed thus far. The ETS began operating in a pilot Phase I on 1 January 2005. The Member State governments granted emissions permits (allowances) for three years until 2007 to factories and power stations, mainly for free. On 15 May 2006, the carbon market crashed: while the market to trade $\mathrm{CO}_{2}$ had almost doubled in a year, more than twothirds of it vanished in three weeks after the May crash. The price of a permit to release a tonne of carbon dioxide plunged $72 \%$ to $€ 8.60$ in three weeks after a series of Member State and Commission reports showed that a surplus had accumulated. This crash reveals a potential implementation problem for the EU, which could undermine its credibility and prospects for prominence at the national and international levels. The future of the EU carbon market is, however, relatively bright. It is now clear that the initial allocations made during the pilot phase were over-estimated, which resulted in allowances of many more $\mathrm{CO}_{2}$ permits than were needed. This problem should be remedied now that emissions have been audited more accurately. As a result, national allocations should be more realistic, which will reduce (but not eliminate) the likelihood of future crashes.

With more accurate allocations reducing the likelihood of another crash, the most important issue for the ETS may be the way in which National Allocation Plans (NAPs) are formulated and approved. These NAPs were recently submitted to the ETS second phase process. ${ }^{27}$ During the initial preparation of the ETS, a formal division of labour was established in which the Commission took responsibility for creating the market mechanism and the Member States took responsibility for the allocations. ${ }^{28}$ This arrangement still allows for a considerable role of the Commission-Member States formulate their individual NAPs, which are then sent to Brussels for the Commission to evaluate and suggest changes before final approval. The Commission uses two criteria for evaluating the NAPs: 1) compatibility with the EU's internal burden-sharing agreement and Kyoto commitments, and 2) national need. The NAPs, however, remain a contentious issue among the Union's environmental "leaders and laggards"

\footnotetext{
${ }^{26}$ Expert Interview, Copenhagen, Denmark 14 March 2007.

${ }^{27}$ For more on the NAPs process, see http://ec.europa.eu/environment/climat/pdf/m06 452 en.pdf.

${ }^{28}$ Expert Interview, Denmark, Copenhagen, 14 March 2007.
} 
(Lenschow 2005: 313-314), and many Member States disagree with the Commission decisions. Indeed, on 1 August 2007, Latvia became the sixth Member State to contest emissions levels and take the Commission to court over specific calculations. ${ }^{29}$

\section{Conclusions: Obstacles and Opportunities at Different Levels}

At first glance, the EU's unique nature might seem to create insurmountable obstacles for any significant role in future climate change policy. It is true that the EU does face a number of domestic obstacles-due to the complex institutional arrangements that pool sovereignty among twenty-seven Member States-that are not faced by individual states and international organisations. In addition, the ad hoc nature of its participation from one international negotiation to the next may be somewhat problematic and its system of shared legal competence can be confusing for third parties.

Despite these obstacles, the EU's position as an authoritative regional point of national and international interaction also provides it with significant opportunities to influence climate change policy at multiple levels. Indeed, it seems to have established itself as a prominent actor in national, regional and international climate change policy-making. Through a number of historical-legal institutional developments, it has overcome obstacles to domestic and international activity in environmental politics. The domestic obstacles have been overcome to a large extent by ECJ decisions, Commission initiatives (like EAPs), new institutions (such as DG Environment and the EEA) and important Treaty changes. Overall, the EU's institutions now seem to operate fairly smoothly according to its own internal procedures and routine monitoring mechanisms. Many international obstacles to its activity have also largely been overcome. It is now recognised by third-party negotiators and very active in global environmental governance. It has received UN recognition, participates in UN negotiations, and has demonstrated an ability to be effective in lengthy UN negotiations.

The EU still faces multiple pressures from different levels that will influence its future role in climate change policy-making. Further studies that investigate both levels will need to take into consideration the various political actors-including individual Member States, regional organisations, international organisations, and non-state actors (e.g., NGOs, political parties, firms, environmentalists, labour, consumers, scientific communities) - and the legal and institutional constraints under which they make decisions.

In the future, much of the EU's domestic and international prominence in this policy area may hinge on the operation of its ETS. At the domestic level, the EU needs to resolve disagreements over the process through which NAPs are decided. But if the EU's internal market for emissions trading enjoys success, it may encourage more innovative solutions to address climate change. Most importantly, in the long-term, this market could also create sufficient incentives to deliver the promised domestic emissions reductions. At the international level, the successful implementation of a fully-functioning ETS should create a first-mover advantage in this lucrative financial service and increase the EU's credibility as a prominent player in the ongoing climate change negotiations. These multiple factors could, therefore, continue to push the EU toward a sustained prominent role in climate change policy.

The year 2012 is fast becoming a crucial juncture by which time a much clearer picture should be available regarding the EU's role and effectiveness in domestic and international climate change politics. At the domestic level, the EU's $6^{\text {th }}$ EAP expires in 2012. The $7^{\text {th }}$ EAP will have to take into consideration a number of important climate

\footnotetext{
${ }^{29}$ The other Member States include Poland, Czech, Slovakia, Hungary, Estonia. See Mahony (2007).
} 
change developments and growing pressures from different levels that have emerged over the last ten years. The Kyoto Protocol also expires in 2012, a deadline that is currently driving international negotiations over what type of system will follow. Developing countries may also start reducing greenhouse gas emissions in 2012-this is particularly important because non-participation by developing countries is currently one of the US's greatest problems with the Kyoto Protocol. Of course, by 2012, the US will have elected a new Administration that could decide to return fully to the negotiating table and challenge EU prominence. This convergence of multiple events suggests that the ongoing European and international negotiations are extremely important for determining the shape of climate change policies to come. We need only watch carefully for the answers as 2012 approaches.

\section{Bibliography}

Andresen, S., and Agrawala, S. (2002). 'Leaders, Pushers and Laggards in the Making of the Climate Regime', Global Environmental Change 12, pp. 41-51.

Barker, T., Kram, T., Oberthür, S. and Voogt, M. (2001). 'The Role of EU Internal Policies in Implementing Greenhouse Gas Mitigation Options to Achieve Kyoto Targets', International Environmental Agreements: Politics, Law and Economics 1, pp.243265.

Braun, M. (2008, forthcoming). 'The Evolution of Emissions Trading in the European Union: The Role of Policy Networks, Knowledge and Policy Entrepreneurs', Accounting, Organizations and Society.

Cass, L. (2005). 'Norm Entrapment and Preference Change: The Evolution of the European Union Position on International Emissions Trading', Global Environmental Politics 5 (2), pp.38-60.

Christiansen, A.C., and Wettestad, J. (2003). 'The EU as a Frontrunner on Greenhouse Gas Emissions Trading: How did it Happen and will the EU succeed?', Climate Policy 3 (1), pp.3-18.

Compston, H. and Bailey, I. (eds.), (forthcoming 2008), Turning Down the Heat: The Politics of Climate Policy in Affluent Democracies. Houndmills, Basingstoke: Palgrave.

Damro, C. (2006). 'The EU and International Environmental Politics: The Challenges of Shared Competence', in K.V. Laatikainen and K.E. Smith (eds.), Intersecting Multilateralisms: The European Union at the United Nations,. London: Palgrave. pp. 175-192.

Damro, C. and MacKenzie, D. (2008, forthcoming). 'Climate Policy and the EU Context', in $\mathrm{H}$. Compston and I. Bailey (eds.), Turning Down the Heat: Climate Policy in Affluent Democracies. Houndmills, Basingstoke: Palgrave.

Damro, C. and Mendez, P.L. (2003). 'Emissions Trading at Kyoto: From EU Resistance to Union Innovation', Environmental Politics, 12 (2), pp.71-94.

Delbeke, J. (ed.) (2006). EU Environmental Law: The EU Greenhouse Gas Emissions Trading Scheme, EU Energy Law, Vol. IV, Leuven, Belgium: Claeys \& Casteels.

Delreux, T. (2006). 'The European Union in international environmental negotiations: a legal perspective on the internal decision-making process', International Environmental Agreements, 6, pp.231-248.

Depledge, J. (2006). 'The Opposite of Learning: Ossification in the Climate Change Regime', Global Environmental Politics 6 (1), pp.1-22.

European Commission (2006). 'Countering Climate Change', EU Insight, Special EU Advertising Supplement, Delegation of the European Commission to the USA, October.

European Commission (2004). 'Global efforts for the environment: Commission and UNEP to reinforce co-operation,' Press Release, IP/04/1115, Brussels, 20 September. 
European Commission (2001). 'Strengthening Europe's Contribution to World Governance', Report of Working Group 5, White Paper on Governance (May), Brussels, Belgium.

Fisher, D.R. (2004). National Governance and the Global Climate Change Regime, Rowman \& Littlefield Publishers, Inc.

Grubb, M., Yamin, F. (2001). 'Climatic Collapse at The Hague: What Happened, Why, and Where to Go from Here?', International Affairs, 77 (2), pp.261-76.

Grubb, M., Vrolijk, C. and Brack, D. (1999). The Kyoto Protocol: A Guide and Assessment, London: The Royal Institute of International Affairs and Earthscan.

Grundig, F. (2006). 'Patterns of International cooperation and the Explanatory Power of Relative Gains: An Analysis of Cooperation on Global Climate Change, Ozone Depletion, and International Trade', International Studies Quarterly, 50, pp.781801.

Gupta, J. and Grubb, M. (eds.) (2000). Climate Change and European Leadership. A Sustainable Role For Europe?, Dordrecht: Kluwer Academic Publishers.

Gupta, J. and Ringius, L. (2001). 'The EU's Climate Leadership: Reconciling Ambition and Reality', International Environmental Agreements: Politics, Law and Economics, 1, pp.281-299.

Harris, P. (ed.) (2007). Europe and Global Climate Change, Cheltanham, UK: Edward Elgar.

Hovi, J., Bang, G. and Bretteville Froyn, C. (2007). 'Enforcing the Kyoto Protocol: Can Punitive Consequence Restore Compliance?', Review of International Studies, 33 (3), pp.435-449.

Hovi, J., Skodvin, T. and Andresen, S. (2003). 'The Persistence of the Kyoto Protocol: Why Other Annex I Countries Move on Without the United States', Global Environmental Politics, 3 (4), pp.1-23.

Janning, J. (2005). 'Leadership Coalitions and Change: The Role of States in the European Union', International Affairs, 81 (4), pp.821-33.

Jupille, J. and Caporaso, J.A. (1998). 'States, Agency, and Rules: The European Union in Global Environmental Politics', in C. Rhodes (ed.), The European Union in the World Community. London: Lynne Rienner Publishers. pp.213-229.

Lenschow, A. (2005). 'Environmental Policy', in H. Wallace, W. Wallace and Pollack, M.A. (eds.), Policy-Making in the European Union, $5^{\text {th }}$ edition. Oxford: Oxford University Press. pp.305-328.

Macrory, R. and Hession, M. (1996). 'The European Community and Climate Change: The Role of Law and Legal Competence', in T. O'Riordan and J. Jäger (es.), Politics of Climate Change: A European Perspective. London: Routledge. pp.106-154.

Mahony, H. (2007). 'Latvia becomes sixth country to fight EU emissions caps', EUObserver, 1 August 2007. Available at: http://euobserver.com/?aid=24557, last accessed 29 September 2008.

Oberthür, S. (2006). 'The Climate Change Regime: Interactions with ICAO, IMO, and the EU Burden-Sharing Agreement', in S. Oberthür and T. Gehring (eds.), Institutional Interaction in Global Environmental Governance. Cambridge, MA: MIT Press. pp.53-77.

Oberthür, S. and Gehring, T. (eds.) (2006). Institutional Interaction in Global Environmental Governance. Cambridge, MA: MIT Press.

Oberthür, S. and Ott, H.E. (1999).The Kyoto Protocol: International Climate Policy for the $21^{\text {st }}$ Century. Berlin: Springer.

Oberthür, S. and Tänzler, D. (2007). 'Climate Policy in the EU: International Regimes and Policy Diffusion', Harris, P.G. (ed.), Europe and Global Climate Change. Cheltanham: Edward Elgar. pp.255-278.

Sbragia, A.M. (1998a). 'Institution-Building from Below and Above: The European Community in Global Environmental Politics', in W. Sandholtz. and A. Stone Sweet (eds.), European Integration and Supranational Governance. Oxford: Oxford University Press. pp.283-303.

Sbragia, A.M. (1998b). 'Environmental Policy', in D. Dinan (ed.), Encyclopedia of the European Union. Boulder, CO: Lynne Rienner Publishers. pp.170-174. 
Sbragia, A.M. and Damro, C. (1999). 'The Changing Role of the European Union in International Environmental Politics: Institution Building and the Politics of Climate Change,' Environment and Planning C, Government Policy. 17, pp.53-68.

Scheipers, S. and Sicurelli, D. (2007). 'Normative Power Europe: A Credible Eutopia?', Journal of Common Market Studies, 45 (2), pp.435-457.

Schreurs, M.A., and Tiberghien, Y (2007). 'Multi-Level Reinforcement: Explaining European Union Leadership in Climate Change Mitigation', Global Environmental Politics. 7 (4), pp.19-46.

Skodvin, T. and Andresen, S. (2006). 'Leadership Revisited', Global Environmental Politics. 6 (3), pp.13-27.

Vig, N. and Faure, M. (eds.) (2004). Green Giants? Environmental Policies of the U.S. and the E.U. Cambridge, MA: MIT Press.

Vogler, J. (2005). 'Europe and Global Environmental Governance', International Affairs $81(4)$, pp.835-850.

Vogler, J. (1999). 'The EU as an Actor in International Environmental Politics', Environmental Politics 8 (3).

Wettestad, J. (2005). 'The Making of the 2003 EU Emissions Trading Directive: An UltraQuick Process due to Entrepreneurial Proficiency?' Global Environmental Politics. $5(1)$, pp.1-23.

Zito, A. (2005). 'The European Union as an Environmental Leader in a Global Environment', Globalizations. 2 (3), pp.363-375. 